\title{
De Slesvigske Kriges kort
}

När vi tender GPS'en i bilen, benytter vi os i realiteten af et redskab, som er udviklet af det amerikanske militer - i erkendelse af, at man ikke kan fore en krig uden at kende bverken slagmarkens landskab eller sin egen position.

Selv med udbredelsen af GPS og digitale kort far Forsvaret stadig, som nogle af de eneste, trykt kort. Kortet er et vigtigt varktøj $i$ militar sammenhang, og gode og pracise kort - eller mangel på samme - kan betyde forskellen på liv og dod.

afph.d.-stipendiat, cand.scient.soc. Stig Roar Svenningsen

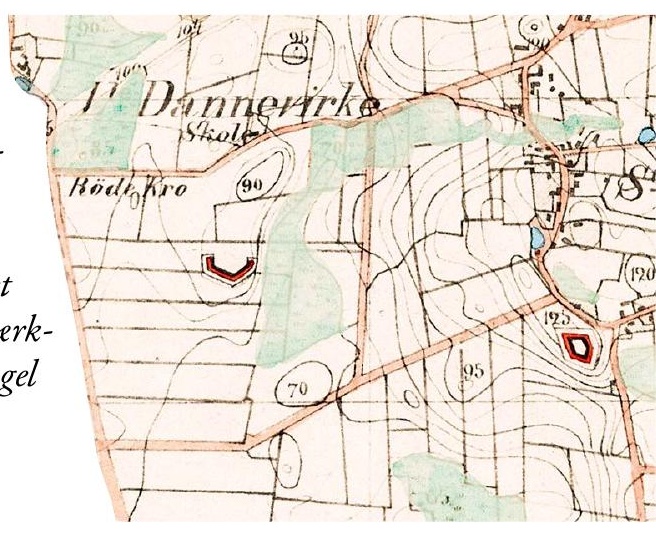
og forskningsbibliotekar, cand.mag. Mette Colding Dahl, Det Kongelige Bibliotek

I

år markeres 150-året for Anden Slesvigske Krig - eller Krigen 1864, som den også kaldes. Krigen, der resulterede i Danmarks tab af hertugdømmerne og dermed Sønderjylland, har altid haft stor historisk interesse både nord og syd for Kongeåen. Senest bl.a. med Tom Buk-Swientys bøger Slagtebank Dybbøl, Dommedag Als og ikke mindst 1864 i billeder, hvor en stor del af billedmaterialet er hentet i Det Kongelige Biblioteks Kort- og Billedsamling.

Blandt de mange levn fra de Slesvigske Krige i Kort- og Billedsamlingen er også landkort. Lige siden fremkosten af de første landkort, har kort været anvendt i krigsførelse. Kort og kartografi blev imidlertid en stadig vigtigere teknologi for militæret i forbindelse med den professionalisering af krigsførelsen, der skete i takt med oplysningstidens teknologiske og videnskabelige udvikling. ${ }^{1}$ Denne udvikling afspejles også under de Slesvigske Krige, hvor den danske hær for første gang anvendte landkort i stor udstrækning.

Men hvilke kort blev egentlig anvendt i de dramatiske kampe i 1864 ?

\section{Manglende kort i 1848}

For at kunne besvare spørgsmålet, må vi først tilbage til Englandskrigene 1807-14 og Første Slesvigske Krig 1848-50. Sagen er nemlig den, at da det i løbet af foråret 1848 stod klart, at det ville ende med en væbnet konflikt i Slesvig og Holsten, var den danske hær fuldstændig uforberedt på krig. ${ }^{2}$ Ikke kun blev garnisonerne i de slesvigske og holstenske byer hurtigt overrendt, men der viste sig også et andet problem for den danske hær, der var sendt til hertugdømmerne for at bekæmpe oprørerne. Man manglede simpelthen brugbare landkort over krigsskuepladsen!

Det var sådan set ikke nogen ny problemstilling, og heller ikke speciel for Slesvig og Holsten. Manglen på brugbare kort havde været kendt siden Englandskrigene. Eksempelvis ved det såkaldte Treskoslag ved Køge Å den 29. august 1807, hvor de engelske landtropper havde nedkæmpet det danske landeværn bl.a. fordi de engelske styrker bedre forstod at udnytte terrænet, og de danske styrker omvendt ikke havde overblik over den vej englænderne angreb. ${ }^{3}$ 
Situationen krævede handling, og året efter, i 1808, blev Generalstaben oprettet med særlig fokus på kortlægning. Naturligt nok koncentreredes kortlægningen om Sjælland og Lolland-Falster. ${ }^{4}$ Det var en logisk konsekvens af, at det var her den sidste krig havde fundet sted, og det derfor var her, man til fulde havde făet illustreret konsekvensen af et manglende kortgrundlag. Med andre ord forberedte man sig - som så ofte både før og siden til den forrige krig!

Det var selvfølgelig ikke sådan, at der i 1848 slet ikke fandtes kort over Slesvig og Holsten. Men af egentlige nyere militære kort fandtes kun den kortlægning, som generalmajor du Plat havde udarbejdet i 1804-05, da hæren var stationeret i hertugdømmerne for at vogte grænsen mod de franske tropper. ${ }^{5}$ Endvidere var der en række kort over garnisonsbyer, enten tegnet som manuskriptkort, eller udgivet i 1821 af Generalkvartermesterstaben, men de var primært beregnet til øvelsesformål, og de dækkede kun landskabet umiddelbart omkring fæstningerne. Af andre officielle kort fandtes kun det forholdsvis moderne Videnskabernes Selskabs kort, der var udgivet 1807-25.

Videnskabernes Selskabs kort var imidlertid ikke egnet til militærbrug. Ikke kun manglede det højdeangivelser af terrænet, det manglede også den detaljeringsgrad, som er nødvendig for den taktiske føring af tropper i krig. ${ }^{6}$ Videnskabernes Selskabs kort var udgivet i en målestok på 1:120.000. Militære kort til brug for kamp i landskabet bør være i målestok 1:20.000-1:50.000, da det først er ved denne målestok, der er plads til at afbilde landskabsdetaljer som eksempelvis hegn og grøfter, som soldaten kan bruge til at søge skjul og dækning i.

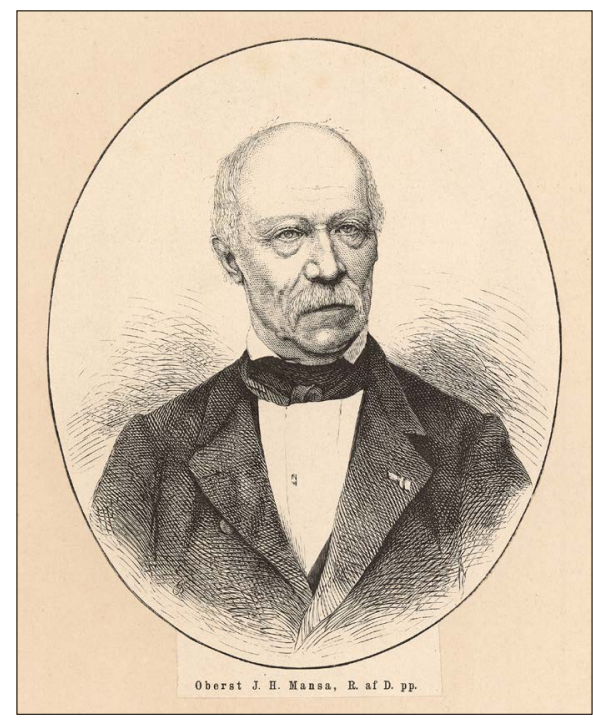

KartografJacob Henrik Mansa (1797-1885). Det Kongelige Bibliotek, Billedsamlingen.

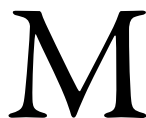
ed den rivende teknologiske og organisatoriske udvikling, der var sket siden midten af 1700-tallet, var kort i 1848 blevet en uvurderlig teknologisk faktor for militæret. ${ }^{7}$ Viden om landskabet havde fået en afgørende rolle i forbindelse med feltslag og militære bevægelser i terrænet. Især under Napoleonskrigene var det tydeligt, at de mere mobile hærstyrker havde brug for gode topografiske kort, som præcist beskrev landskabets struktur i form af bygninger, veje, hegn, moser, skov og højdeforhold. Sådanne detaljerede kort var et uvurderligt værktøj for officerer til at træffe beslutninger om placering af tropper, og det var netop det, de danske tropper blandt andet havde manglet under Englandskrigene.

Selvom den officielle militære kortlægning var koncentreret om den sjællandske øgruppe, var der dog to ildsjæle, der forsøgte at afhjælpe situationen. Dels ved 


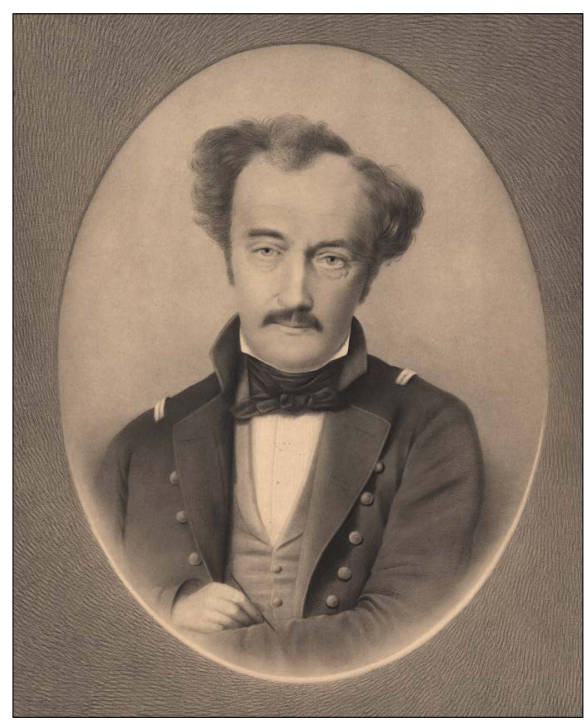

Generalstabsofficer O.N. Olsen (1794-1848). Det Kongelige Bibliotek, Billedsamlingen.

at nyudgive en række af Videnskabernes Selskab kort, dels ved egen nyproduktion. Den ene var generalstabsofficeren Oluf Nicolai Olsen, som gjorde en ihærdig indsats for at få udbredt den topografiske kortlægning af Danmark. Han virkede dels som den første chef for Generalstabens Topografiske Afdeling fra 1842 til sin død i 1848, dels som privat udgiver af kort. Den anden var officeren og kartografen Jacob Henrik Mansa. Han udgav som privatperson en række landkort i form af Atlas over Danmark i perioden 1837-48. Mansas kort var baseret på indsamling af geografiske oplysninger fra matrikelkort, som efterfølgende blev kontrolleret i felten. ${ }^{8}$

Olsen og Mansa producerede også en række kort over Slesvig og Holsten. Olsen udgav i 1836 et kort i målestok 1:240.000, der var baseret på en revideret udgave af Videnskabernes Selskabs kort. Det var selvfølgelig langt fra det præcise kort, som en hær i krig har brug for, men det tilvejebragte dog en opdateret udgave af Videnskabernes Selskabs kort. Lidt bedre var Mansas kort, der - til trods for mangler - var bedre til at afbilde terrænet, eftersom det var i målestok 1:160.000. Selvom både Olsens og Mansas kort var klar ved krigsudbruddet i 1848, afhjalp de imidlertid ikke manglen på brugbare kort. Ifølge den officielle historie om krigen $\mathrm{i}$ 1848 udgivet af Generalstaben, var kortene nemlig ikke egnet til militært brug på slagmarken. ${ }^{9}$ Alligevel blev de anvendt i forholdsvis stor udstrækning, men mest som oversigtskort.

\section{Kort i Første Slesvigske Krig 1848-50}

Manglen på brugbare kort afspejlede sig tydeligt i den danske krigsførelse, især i krigens første år. Hæren var nødsaget til at foretage rekognosceringer og udarbejde grundige terrænbeskrivelser før hver eneste større militære operation for at kompensere for det manglende kortgrundlag. Generalstabens officielle historie om krigen i 1848 er nærmest en endeløs beskrivelse af rekognosceringsmissioner. ${ }^{10}$ Forbruget af kort under Første Slesvigske Krig var i det hele taget beskedent. I 1848 blev der udleveret 547 kort til en hærstyrke på 11.000 mand. Derudover blev der trykt 300 eksemplarer af Olsens udgave af Videnskabernes Selskabs kort i 1849. ${ }^{11}$

Manglen på brugbare militærkort var imidlertid ikke kun et dansk problem: Oprørshæren manglede i den grad også kort. Oprørshæren var dog yderligere begrænset i sin adgang til landkort, da salget af de udgivne danske kort selvsagt stoppede ved krigsudbruddet. ${ }^{12}$ Derfor udgav den slesvig-holstenske generalkvartermester F. Geertz et kort over Slesvig i målestok 1:80.000, hvilket var en 


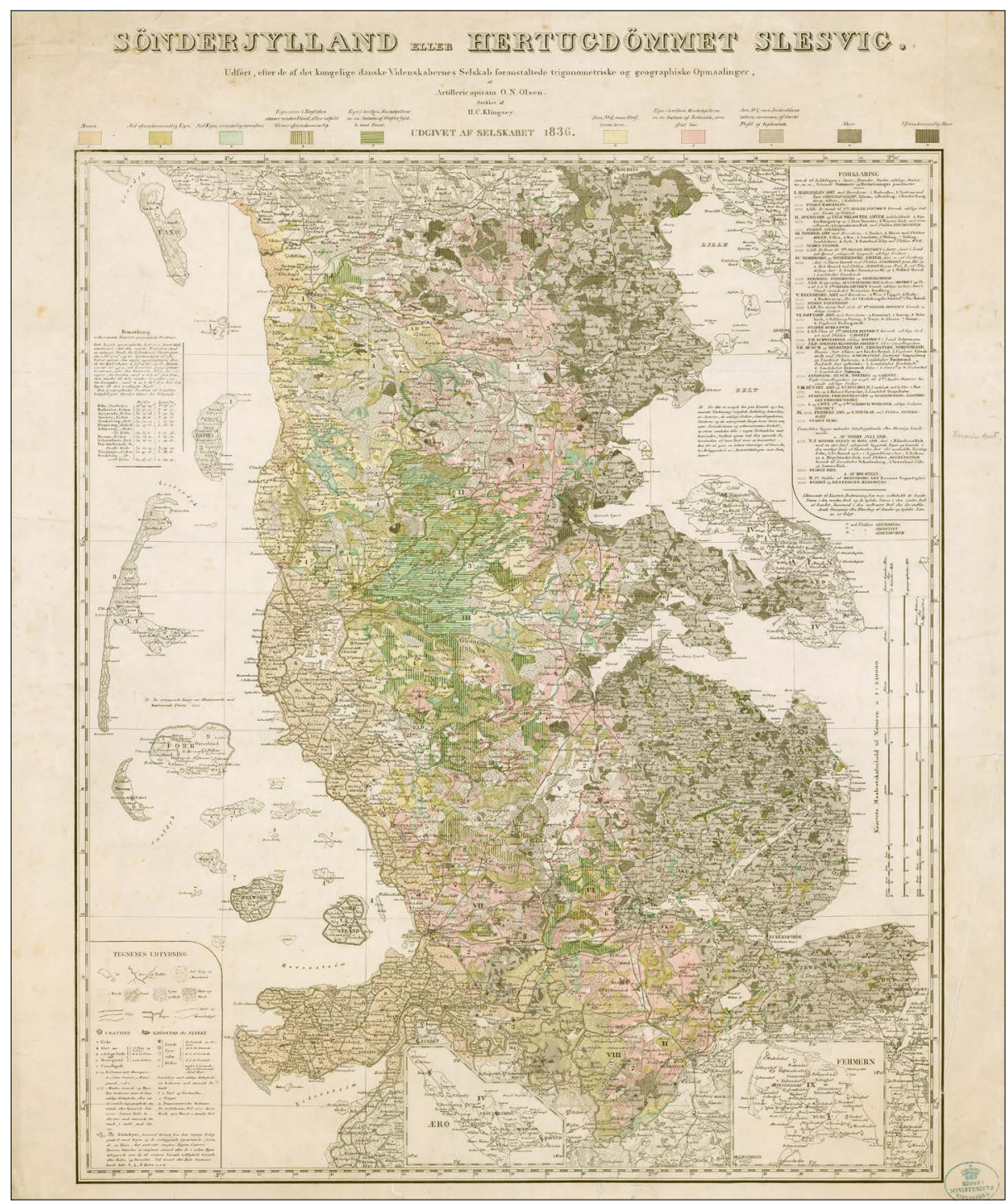

O.N. Olsens kort fra 1836 i to forskellige udgaver. Kortet på denne side er farvelagt som militergeografisk kort, mens kortet på modstående side viser de administrative granser. Kortsamlingen.

betydelig bedre målestok end de tidligere kort. Det slesvig-holstenske kortværk var imidlertid ikke nogen nyhed. Det var hovedsagelig baseret på kopier af eksisterende kort; eksempelvis Mansas kort over
Jylland kombineret med lokale matrikelog sognekort litograferet til sammenhængende kort. ${ }^{13}$ Under krigen producerede den danske hær også en række kort til militært brug i bedre målestok. Områ- 


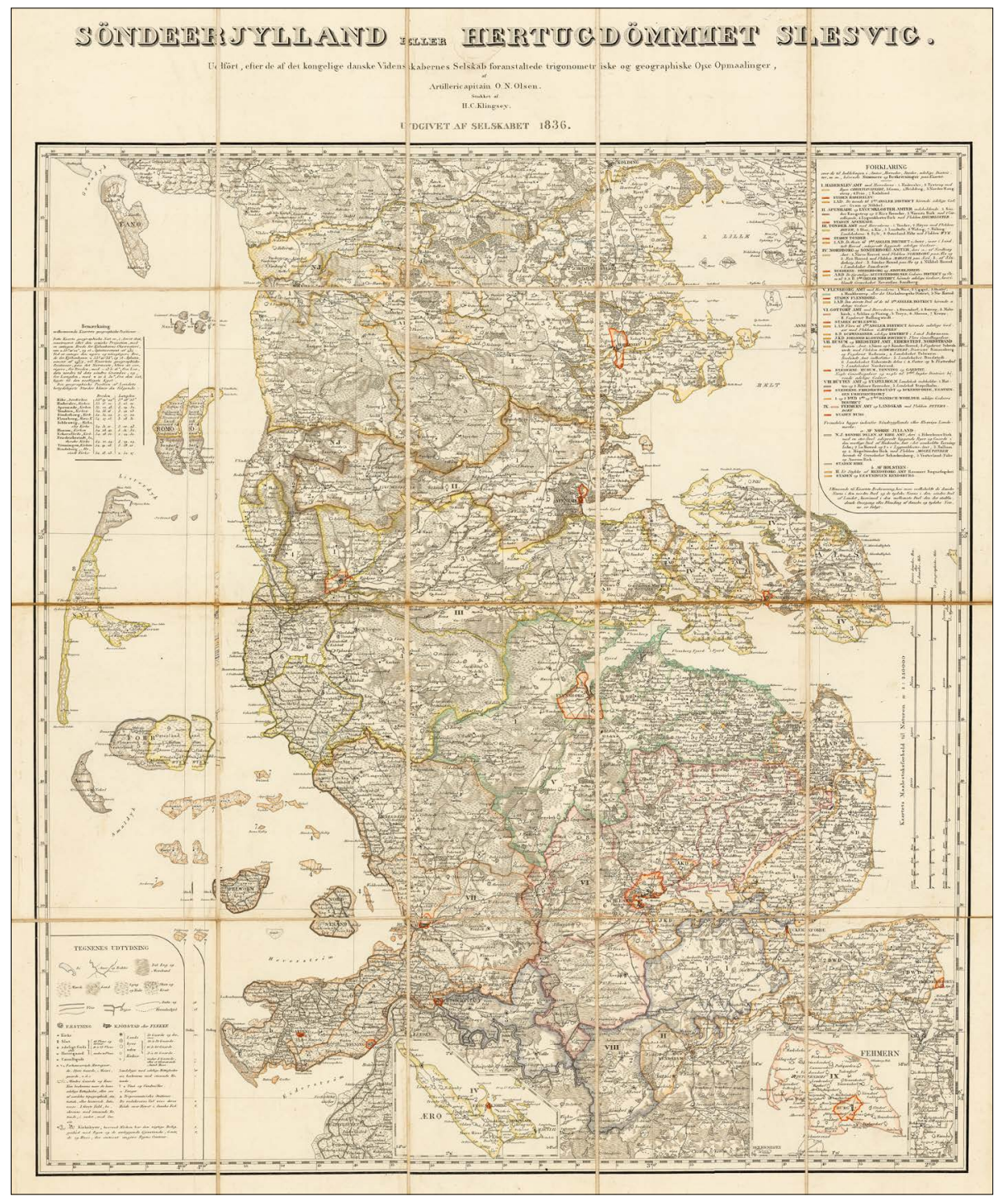

der med intensive kamphandlinger blev prioriteret. Eksempelvis blev egnen omkring Eckernförde, Fredericia, Flensborg, Frederiksstad, Slesvig og Sorgfloden ved Ejderen kortlagt i perioden 1848-50 i målestok 1:40.000. ${ }^{14}$
Det Kongelige Biblioteks Kortsamling har en række eksempler på kort anvendt i Første Slesvigske Krig. En del af kortene er købt på auktion, mens andre er kommet til biblioteket via aflevering fra myndigheder eller som gaver fra privat- 
personer. Der er altså tale om kort, der har været anvendt - måske endda udleveret til deltagere $-i$ krigen. Kortenes overleveringshistorie giver os derved mulighed for at se, hvordan kortene blev brugt $\mathrm{i}$ samtiden.

Trykketeknikken i 1800-tallet gav kun i begrænset omfang mulighed for at trykke kort med flere farver. Topografiske kort med farvetryk kendes først fra omkring slutningen af det 19 . århundrede. ${ }^{15}$ Kortenes brugere skulle derfor selv farvelægge de forhold på de sort/hvide kort, som de gerne ville fremhæve. Det kunne f.eks. være de topografiske elementer i landskabet, som skove, marker og moser, eller det kunne være administrative grænser. På den måde gav de sort/hvide kort mulighed for en flersidig anvendelse, der kunne tilpasses brugerens behov.

Kortene blev oftest farvelagt med henblik på at give overblik over mulighederne for færdsel på tværs af landskabet. Dette var især gældende for de detaljerede kort, som skulle bruges til at føre tropperne i kamp. Denne form for fremhævning af færdselsmulighederne i terrænet kan også findes på oversigtskort i lille målestok, som eksempelvis Olsens udgave af Videnskabernes Selskabs kort fra 1836.

\section{Kortlægningen af Slesvig 1851-54}

Manglen på opdaterede kort må have givet stof til eftertanke for hærledelsen, for efter krigen i 1851 besluttede man fra dansk side at få udarbejdet et nyt kort over Slesvig. Under ledelse af officeren Edward Klingsey ${ }^{16}$ blev Slesvigs fastland kortlagt i perioden 1851-54. Man anvendte her den grundlæggende opmåling fra Videnskabernes Selskabs kort i målestok 1:20.000 som skelet for en militær terrænbeskrivelse. Selve terræn- beskrivelserne blev udarbejdet af yngre officerer i form af et manuskriptkort med forklarende tekst. Efterfølgende blev de enkelte rekognosceringskort anvendt som grundlag for udarbejdelsen af et samlet kort i seks dele i målestok 1:120.000 over Slesvig. Kortet blev udgivet som sort/hvid tryk af Generalstaben i $1858 .{ }^{17}$ Dermed havde man fået et officielt militært kort over Slesvig.

Kortlægning var et omfattende arbejde, hvilket antallet på over 50 officerer, som var involveret i projektet, vidner om. Sjovt nok kom de hovedsageligt fra infanteriet og jægerbataljonerne, og var derfor ikke beskæftiget med kortlægning til daglig. ${ }^{18}$ De egentlige topografer fra Generalstaben var nemlig travlt optaget med kortlægningen af Sjælland, Fyn og Lolland-Falster - noget som tilsyneladende blev prioriteret højere.

Rekognosceringskortene er på grund af deres detaljerede beskrivelser af terrænet en god kilde til landskabets historie i den del af Danmark, som på grund af nederlaget i 1864 ikke blev inkluderet $\mathrm{i}$ førsteudgaven af Generalstabens målebordsblade, der ved sin udgivelse i anden halvdel af det 19. århundrede blev den første samlede og detaljerede landsdækkende kortlægning af Danmark.

I 1864 udgav Generalstaben et lignende kort over Holsten og Lauenborg i otte kortblade. ${ }^{20} \mathrm{Vi}$ ved i dag ikke meget om det kortlægningsarbejde, som gik forud for kortet. Det er dog sandsynligt, at det blev produceret efter samme metode som kortet over Slesvig. Den udgave af kortet, som findes i Det Kongelige Biblioteks Kortsamling, er forsynet med tysk tekst. Det er et ejendommeligt valg fra Generalstabens side, set i lyset af pro- 


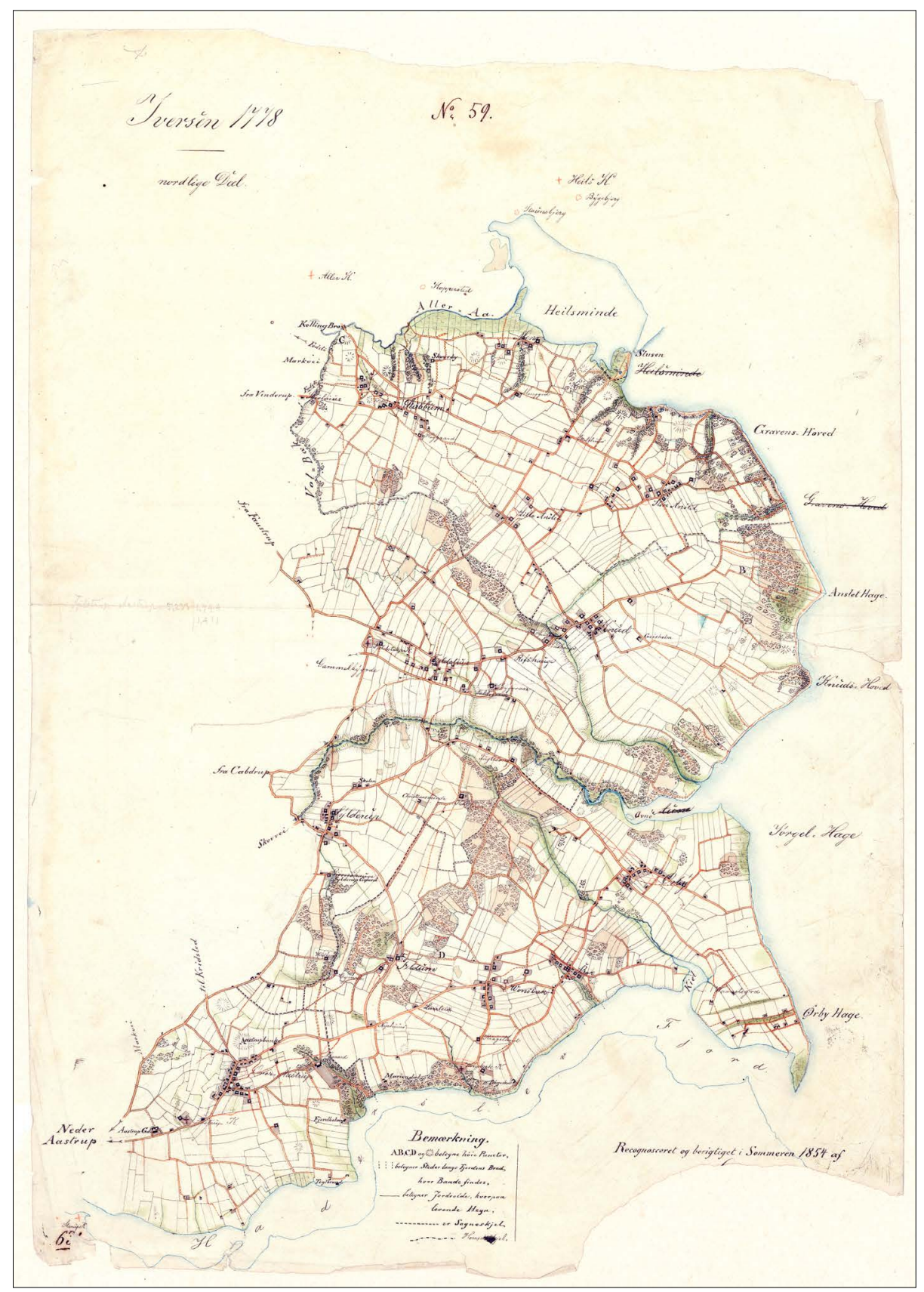

Manuskriptkort over Ørby Hage nord for Haderslev Fjord. Til kortet hører også en langere beskrivende tekst, som i dag kan findes på Rigsarkivet. ${ }^{19}$ (c) Geodatastyrelsen 2014.

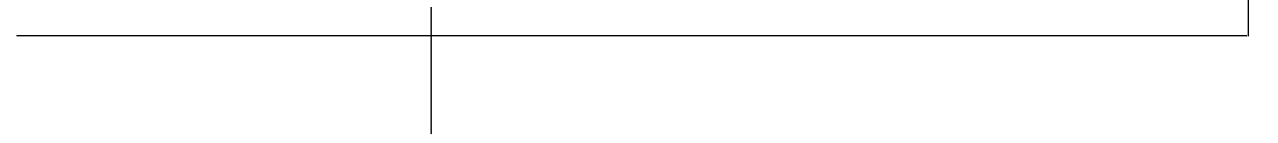




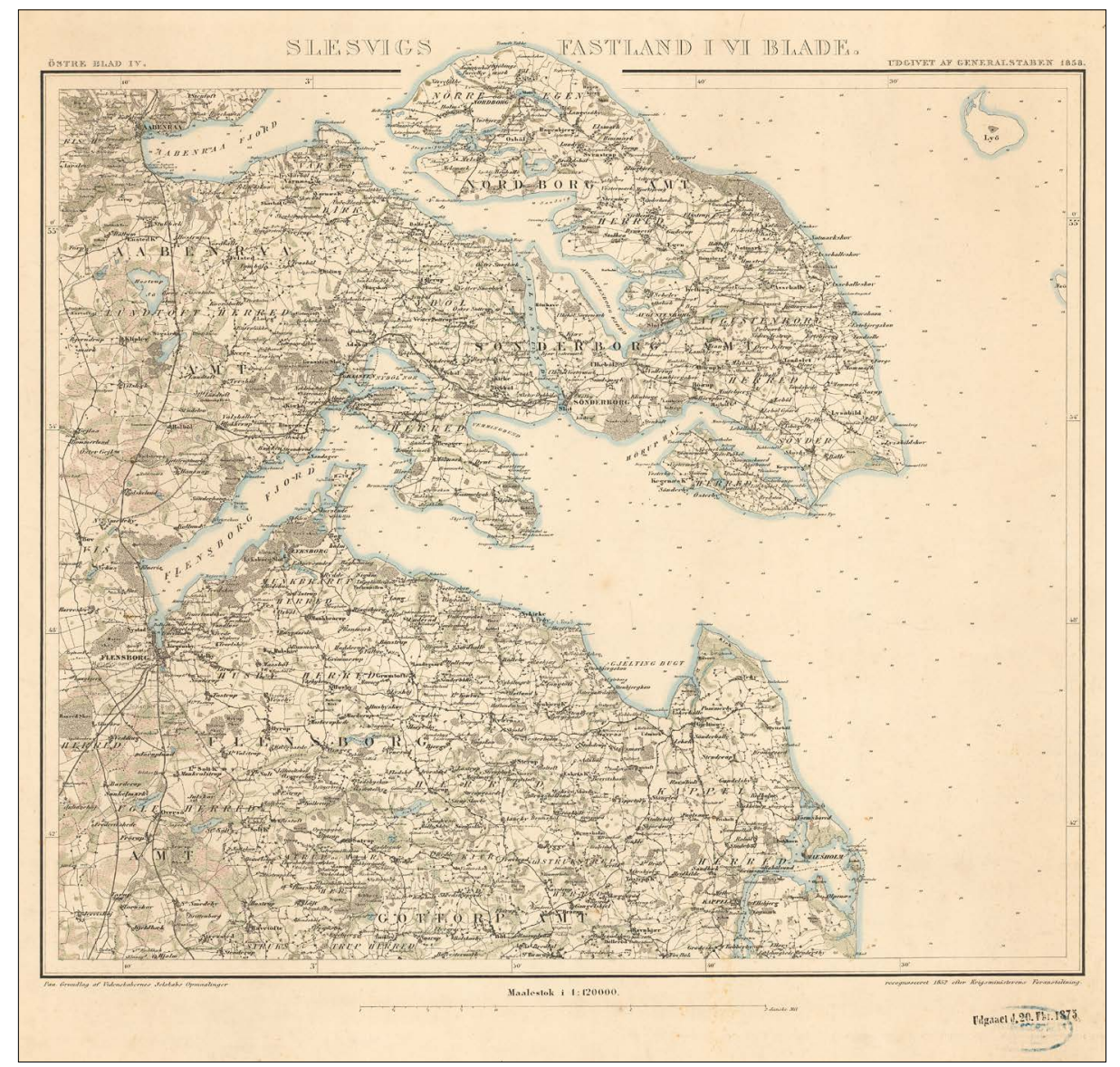

Östre blad IV. Kortblad fra kortverket over Slesvigfra 1858. Kortet er efterfolgende farvelagt med henblik på at fremheve skove, moser, heder og omräder med vand. I andre eksemplarer er det de administrative granser, der er frembevet. Det Kongelige Bibliotek, Kortsamlingen.

blemet med den tyske kopiering af danske kort under krigen i 1848-50.

\section{Kort over Slesvig og Krigen 1864}

Ved indgangen til Anden Slesvigske Krig i 1864 burde den danske hær således have været velforsynet med brugbare militærkort. Det var imidlertid ikke tilfældet. Godt nok havde man kortværkerne i 1:120.000 over Slesvig fra 1858 og over
Holsten og Lauenborg fra 1864 samt en lang række af de mange detaljerede kort fra opmålingerne under Første Slesvigske Krig i 1848-50. Men efterfølgende var arbejdet gået i stå, og de detaljerede topografiske kort, der var så nødvendige for hæren, manglede i vid udstrækning. Kortlægningsarbejdet ved Generalstabens Topografiske Afdeling var stort set blevet prioriteret til Fyn og en fortsættelse af 


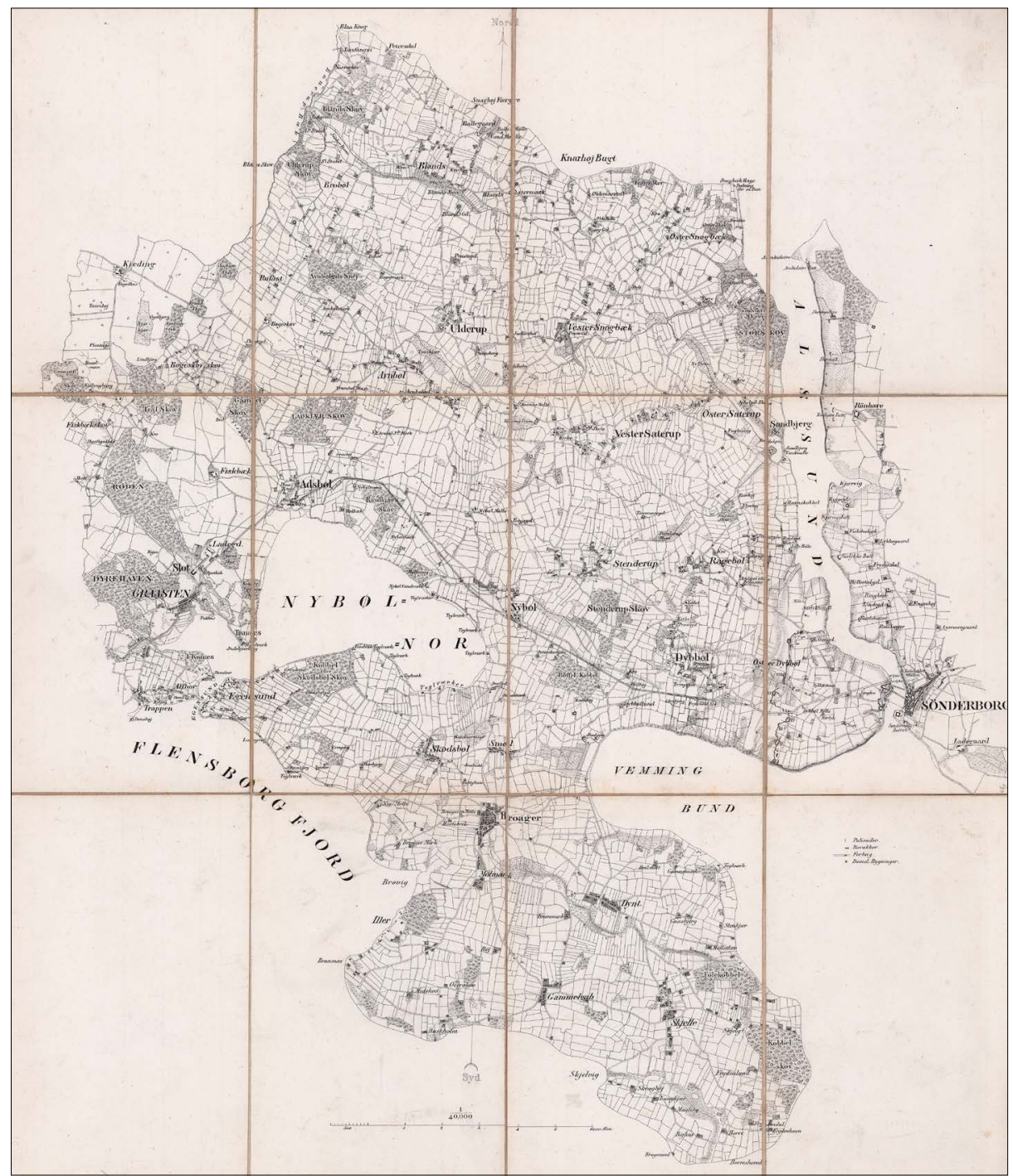

Kort over Sundeved med Dybbolstillingen og Broagerland fra 1864 i målestok 1:40.000. Kortet blev fremstillet $i$ al hast under krigen $i$ 1864, og var en opdateret udgave af kortet fra 1851 baseret på Videnskabernes Selskabs opmåling. Denne udgave er opklebet på larred for at lette brugen ifelten. Kortsamlingen, Det Kongelige Bibliotek.

Sjælland og Lolland-Falster. Afdelingen havde også skulle afgive arbejdskraft til brug ved opmålingsarbejder ved etablering af jernbaner. Derfor måtte Gene- ralstabens topografer på overarbejde, da hæren blev mobiliseret. Det lykkedes imidlertid i al hast at opdatere og litografere en række brugbare terrænkort 


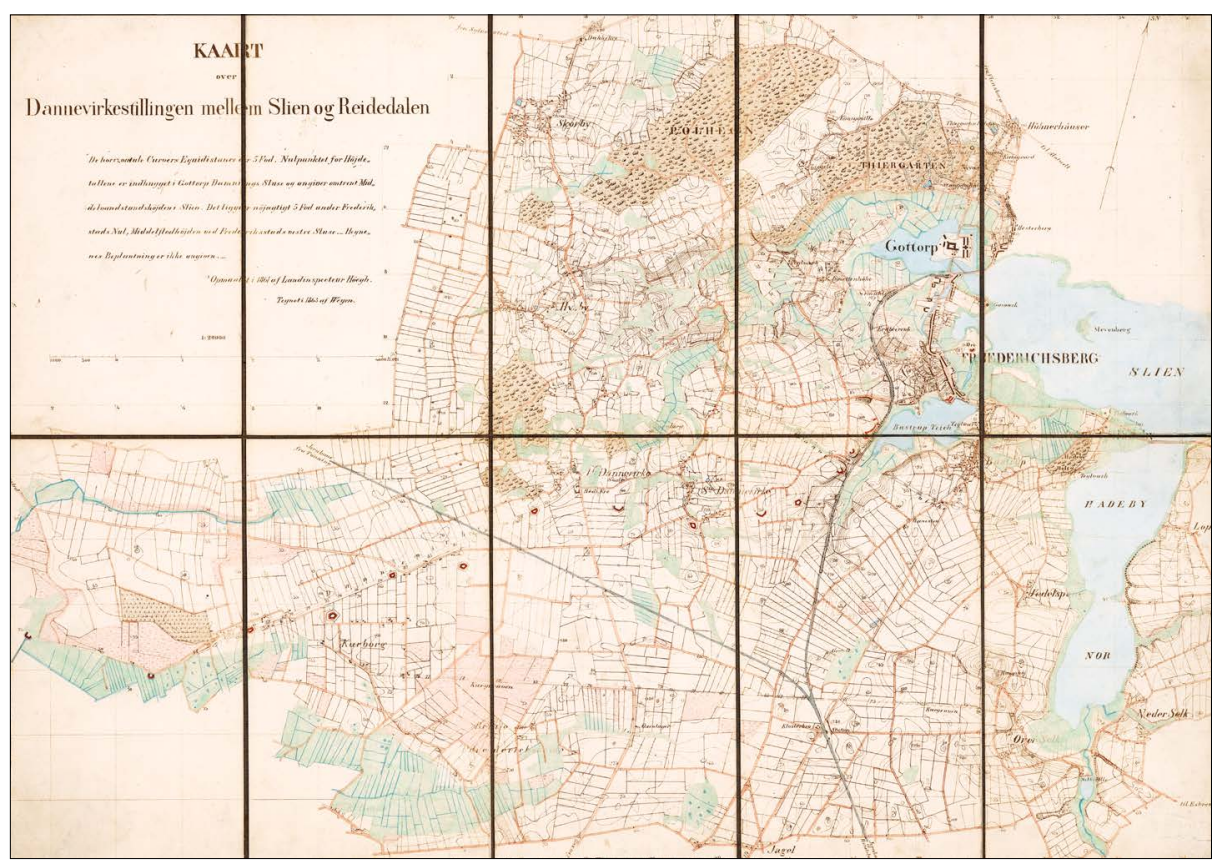

Kort over Dannevirkestillingen mellem Slien og Reidedalen i målestok 1:20.000 fra 1863 opmailt af landinspektor Höegh i $1861 \mathrm{og}$ tegnet af Weyem i 1863. Udgaven er håndkoloreret og med angivelse affestningsverker. Kortet er endvidere opklabet på larred for at lette brugen $i$ felten. Kortsamlingen, Det Kongelige Bibliotek.

i målestok 1:40.000 over Fredericia og Dybbøl-Sundeved i vinteren $1864 .^{21}$

Hæren var dog langt bedre udrustet med anvendelige militære landkort i 1864 end tilfældet havde været i 1848. Det afspejles også i forbruget af kort. I løbet af den godt seks måneder lange krig blev der udleveret 7.967 kort mod 547 i hele 1848 . Ser vi nærmere på hvilke kort, der blev udleveret, tegnede forskellige versioner af kortværket fra 1858 sig for hele $43 \%$ af de udleverede kort - godt 3.438 stk. i alt. Endvidere var kortet over Sundeved, som også viste Dybbølstillingen, et ganske populært kort, og der blev udleveret 1.168 stk. Interessant nok fik hæren også udleveret 1.806 stk. af kortet over Holsten og Lauenborg fra 1864, hvilket vel vidner om en vis optimisme i de danske militære stabe! Mansas privatudgivne kort, især over Jylland, var dog også stadig i udbredt brug. $^{22}$

Selvom en soldat i 1864 havde en større sandsynlighed for at støde på et brugbart kort end godt 16 år tidligere i 1848, var den del af hærens udrustning ikke blevet forbedret i nær så høj grad, som forbedringer i opmålings- og trykketeknikken muliggjorde. Derved indskriver historien om kortene fra de Slesvigske Krige sig som endnu et eksempel på den manglende militære forberedelse bag den konfrontatoriske udenrigspolitik op til krigen i $1864 .^{23}$ 
Som svar på spørgsmålet om, hvilke kort der blev anvendt i kampene ved Dybbøl og Als i foråret og sommeren 1864, kan vi altså med rimelighed gå ud fra, at mandskabet i skanserne på Dybbøl planlagde deres operationer med det detaljerede kort som i al hast blev produceret i 1864 . Under tilbagetrækningen fra Dannevirke til Dybbølstillingen og under resten af krigen, har kortene fra rekognosceringen af Slesvig $i$ 1851-54 nok været det dominerende kort. Paradoksalt nok manglede der tilsyneladende kort over selve Dannevirkestillingen, der havde så stor symbolsk betydning $\mathrm{i}$ den danske selvforståelse. Hæren måtte her forlade sig på et kort udarbejdet af landinspektør Höegh og kartograf Weyem i perioden 1861-63. Kortene har derfor hovedsageligt været oversigtskort, som ikke

\section{Noter}

1 Jeremy Black: A Revolution in Military Cartography? Europe 1650-1815; The Journal of Military History 73, no. 1, 2009, s. 65f. Denne professionalisering kulminerede i Danmark med etableringen af Generalstabens Guidekorps i 1808, der havde specifikt fokus på udarbejdelsen af militære landkort. Jfr. E.O.A. Hedegaard: Generalstabens guidekorps. Et bidrag til Generalstabens og Underofficerskorpsets historie. 1968.

2 Hans Christian Bjerg \& Ole Louis Frantzen: Danmark i krig. 2005, s. 271-272.

3 Kjeld G.H. Hillingsø: Landkrigen 1807. 2007, s. 121.

4 Stig Roar Svenningsen \& Andreas Aagaard Christensen: Mapping the Nation for War: Representations of the Landscape in Danish Military Cartography 1800-2000. Paper presented at the 25th International Conference on the History of Cartography, Helsinki, 2013. har vist mange detaljer af det terræn, der blev kæmpet i.

De Slesvigske Kriges kort var altså langt fra så præcise og detaljerede, som de med datidens teknologi kunne have været. Men når vi i dag bedømmer de anvendte kort, må det ske i lyset af, at udarbejdelsen af et landsdækkende militærtopografisk kort først var blevet indledt godt 40 år tidligere i 1808. Det lykkedes jo at få produceret detaljerede topografiske kort i den periode, bare ikke over Slesvig. Efter krigen kom den landsdækkende kortlægning i gang igen og med et højere momentum, og i løbet af en periode på 34 år blev resten af landet kortlagt i målestok 1:20.000. Denne opmåling dannede grundlag for udgivelsen af topografiske kort langt ind i det 20 århundrede.

5 Peter Korsgaard: Kort som kilde: en haindbog om historiske kort og deres anvendelse. 2006, s. 67.

6 P.G. Henriksen: Herkort $i$ Danmark og nabolande gennem tiderne. 1971, s. 62.

7 Jeremy Black: A Revolution in Military Cartography? Europe 1650-1815; The Journal of Military History 73, no. 1, 2009, s. 49-68.

8 Bjørn Westerbeek Dahl: Samlet, tegnet og lithographeret af J.H. Mansa; Krigshistorisk Tidsskrift 22, no. 3, 1986, s. 80-87.

9 C.M.W. Tvermoes \& J.C. Pingel: Den dansk-tydske Krig i Aarene 1848-50; 1ste Del: Krigen i 1848., Afsnit 1: Fra det slesvig-holstenske Oprørs Udbrud til Preussernes Optræden på Kamppladsen: 24de Marts-12te April. 1867, s. 185.

10 Ibid.

11 P.G. Henriksen: Herkort i Danmark og nabolande gennem tiderne. 1971, s. 61. 
12 F. Geerz: Beretning om kort fra krigsskuepladsen i Slesvig i 14 sektioner om kortene over omegnen af Kolding, Vejle, Fredericia og Christiansfeld i 4 blade. 1851 (genoptr. 1968).

13 Ibid.

14 P.G. Henriksen: Herkort i Danmark og nabolande gennem tiderne. 1971, s. 45.

15 Ibid. s. 35

16 Bror til Poul Klingsey, som senere blev chef for Generalstabens Topografiske Afdeling i en kortere periode i 1876.

17 "Edvard Klingsey" i Dansk Biografisk Leksikon, <www.denstoredanske.dk>.
18 Regneark på baggrund af kort fra Geodatastyrelsen.

19 Rigsarkivet: 0201-022 Generalstaben, Krigsføringsdepotet A. Sagsakter 17801943 VI Topografi, PK 151

20 P.G. Henriksen: Herkort i Danmark og nabolande gennem tiderne. 1971, s. 46

21 Ibid. s. 62

22 P.G. Henriksen: Herkort i Danmark og nabolande gennem tiderne. 1971, s. 63.

23 Claus Bjørn \& Carsten Due-Nielsen, Dansk udenrigspolitiks historie 3. Fra Helstat til Nationalstat. 2006, s. 239-240. 